\title{
Response of Selected Cassava Varieties to the Incidence and Severity of Cassava Brown Streak Disease in Tanzania
}

\author{
Gration M. Rwegasira ${ }^{1} \&$ Chrissie M. E. Rey ${ }^{2}$ \\ ${ }^{1}$ Department of Crop Science and Production, Sokoine University of Agriculture, Tanzania \\ ${ }^{2}$ School of Molecular and Cell Biology, University of the Witwatersrand, South Africa \\ Correspondence: Gration M. Rwegasira, Department of Crop Science and Production, Sokoine University of \\ Agriculture, P. O. Box 3005 Chuo Kikuu, Morogoro, Tanzania. Tel: 255-754-595-058. E-mail: \\ grwegasira@yahoo.co.uk
}

Received: January 19, 2012 Accepted: February 6, 2012 Online Published: June 19, 2012

doi:10.5539/jas.v4n7p237

URL: http://dx.doi.org/10.5539/jas.v4n7p237

\begin{abstract}
Cassava brown streak virus disease (CBSD) has been a serious and most damaging disease in cassava crop throughout the East, Central and Southern part of Africa. Several cassava varieties invariably respond to the disease, but the effect of the disease on affected varieties was not known. The current study was conducted to assess the ability of some farmer-preferred CBSD-affected varieties to withstand the disease. Field experiments were conducted at Kibaha Agricultural Research station from 2006 to 2008. The inherent variety characteristics influenced the incidence and severity levels of CBSD in the test plants. Leaf and stem CBSD incidences and severities, root weight and number of whiteflies (vectors) were significantly $(\mathrm{P}<0.001)$ related to the individual variety. Varieties Albert, Cheupe, Kibaha and Nachinyaya were seriously affected. The CBSD incidences and severities in these varieties increased with plant age, with highest disease records starting at nine to twelve months after planting. Dual infections of CBSD and CMD were recorded in four (Cheupe, Kibaha, Namikonga and Nachinyaya) of the five test varieties. Namikonga was proven to be resistant to CBSD. The correlation analysis suggested a significantly positive relationship between the perceived disease vector, Bemisia tabaci and the incidence and severities of CBSD and CMD. It was concluded that different varieties responds differently to CBSD and the disease severity increases with plant age.
\end{abstract}

Keywords: Cassava brown streak disease, variety response, disease progress, severity

\section{Introduction}

Cassava (Manihot esculenta Crantz) is an important source of food and cash for most families in rural areas and peri-urban centers in Tanzania. The crop is grown in 22 out of 26 regions (Mkamilo, 2009), the Lake zone being the lead producer. Cassava is produced on about $1,107,118.12$ ha with total fresh root production of 7,000,000 metric tones (FAOSTAT, 2008). Despite its importance, cassava is highly affected by viral diseases particularly the Cassava brown streak disease (CBSD).

Cassava brown streak disease has for long been known to be caused by Cassava brown streak virus (CBSV) (Monger et al., 2001). Recent findings have indicated that CBSD may sometimes be caused through mixed infection of the two entirely different viruses of Cassava brown streak virus (CBSV) and Ugandan cassava brown streak virus (UCBSV) (Mbanzibwa et al., 2009). Both viruses belong to the genus Ipomovirus in the family Potyviridae (Adams et al., 2005; ICTV, 2005; Monger et al., 2001a). The disease was reported for the first time in East African coast since 1936 (Storey, 1936), as one of the most damaging viral disease of cassava. Although the disease is primarily known to spread through infected planting materials, other workers (Maruthi et al., 2005; Ntawuruhunga \& Legg, 2007) have attributed its spread to the whitefly vector, Bemisia tabaci Genn. The tuberous yield loss caused by CBSD has been estimated at more than $70 \%$ per plant (Hillocks et al., 2001). The disease is known to occur in various countries including Kenya, Malawi, Mozambique, Tanzania and Uganda (Nichols, 1950; Jennings, 1960, Hillocks and Jennings, 2003). Other countries recently reported to be affected are Burundi, Democratic Republic of Congo, Rwanda and Zambia (Alicai et al., 2007; EARRNET, 2005).

After infection of susceptible plants, the virus triggers development of symptoms usually considered indicative of the disease (Alicai et al., 2007). These are often expressed as chloroses and necroses in leaves, stems and roots. Initial description of the disease symptoms were given by Storey (1936 \& 1939) but more comprehensive 
descriptions were subsequently provided by Nichols (1950), Hillocks and Thresh (1998) and Hillocks and Jennings (2003).

Variation among cassava cultivars in expressing root and foliar symptoms of CBSD has been reported (Hillocks \& Jennings, 2003; Jennings, 1957; 1960). The inherent characteristics of the susceptibility or resistance of the respective variety leads to varied response to CBSV infection (Hillocks et al., 2001). Most susceptible cultivars exhibits pronounced foliar and root symptoms, and the syndrome begins soon after sprouting in the cutting-derived infection. Some cultivars develop mild root symptoms without foliar symptoms (Hillocks \& Jennings, 2003; Rwegasira, 2009). In most instances stem symptoms starts as minor necrotic spots which fuse into bigger necrotic lesions culminating into shoot die-back as most of tender portion of stem becomes necrotic (Hillocks \& Jennings, 2003). Shoot die-back is often associated with root necrosis (Nichols, 1950).

CBSV-infected susceptible cultivars tend to obviously exhibit the foliar, stem and root symptoms while the resistant cultivars tend to undergo active growth giving no time for the expression of CBSD symptoms (Storey \& Doughty, 1951). The necrotic tissues are often compressed against the bark and are frequently occluded (Hillocks \& Jennings, 2003). This is common during re-growth triggered by rains after a period of reduced growth usually experienced in the dry season (Hillocks \& Jennings, 2003; Legg \& Hillocks, 2003). Limited foliar symptoms without or with delayed root symptoms has for instance, been reported in a few resistant cultivars like Nachinyaya (Hillocks et al., 2001).

Plant age also affects symptoms expression in CBSD-affected plants (Hillocks et al., 1999). The leaf symptoms become more difficult to recognize in older plants as most of the lower leaves are shed (Hillocks \& Jennings, 2003) although in some cultivars like Kibaha, failed shedding of senesced leaves has been recorded (Rwegasira, 2009). In the absence of senesced symptomatic leaves, die-back remains the only above ground diagnostic symptom (Nichols, 1950). Since die-back is not a common character in most varieties (Hillocks, 1997), the observed plants may be regarded free from CBSV despite being infected. Thus, the leaf symptoms and probably the root symptoms would at times be the only reliable diagnostic symptoms.

The reported variability in the magnitude of symptom expressions among CBSD-affected cultivars when grown in different environments (Jennings, 1957; Munthali, 1992; Nichols, 1950) triggered a need to determine the response of some of the currently farmers and researchers preferred cultivars to the disease. The need to determine rate of symptom expression on each diagnostic plant parts was paramount. The current study aimed at; (i) determining the response of different cassava cultivars with varied susceptibility to CBSD, (ii) examining the disease progress with respect to plant age and weather parameters particularly the rainfall and temperature, and (iii) assessing the relationship in symptoms expression among different parts of the CBSD-affected plants.

\section{Materials and Methods}

Field experiments were conducted at SRI-Kibaha, Tanzania in two consecutive seasons, June 2006/July 2007 and July 2007/August 2008 to determine the susceptibility of selected cultivars to CBSD. Five cultivars with varying levels of sensitivity to CBSD namely: Albert, Cheupe, Kibaha, Nachinyaya and Namikonga were randomized using a standard statistical table for random numbers planted in a Randomised complete block design (RCBD) with three replications. Stem cuttings $(25-30 \mathrm{~cm}$ long) were obtained from CBSD-affected plants (symptom severity score 2-5, except for Namikonga which rarely manifested CBSD symptoms) of each of the five cultivars and planted at $1 \mathrm{~m} \times 1 \mathrm{~m}$ spacing. The overall plot size per variety in each replication was $6 \mathrm{~m} \times 8 \mathrm{~m}$ with a net plot comprised of 36 plants in six rows for each cultivar, bordered on either side by six plants of a CBSD-tolerant cultivar, Namikonga. The cultivar, Namikonga was included as a control. The inter-plot space was $2 \mathrm{~m}$ and space between blocks (replications) was $3 \mathrm{~m}$. Each cultivar was replicated three times. Thus, a total of 108 plants were assessed per cultivar.

Monthly assessments were made based on leaf and stem symptoms to determine incidence and severity of CBSD in each of the five cultivars. The disease incidence was recorded as percentage proportion of the symptomatic tissue to the whole surface area of the assessed tissues and disease severity score scale of $0-5$ was used on CBSD severity assessment. The Hillocks and Thresh (1998) CBSD assessment scale of 1 (no symptoms) through 5 (severe symptoms) was used with minor modification as presented in Table 1 due to greater diversity in symptoms expression that was observed among the susceptible and CBSD-resistant varieties. The modifications made includes adjustment of the disease incidence score scale where by 'score 3' formerly representing a 5-12\% incidence was adjusted to 5-30\%; 'score 4 ' formerly representing a $>12-25 \%$ incidence was adjusted to $>30-50 \%$; and 'score 5 ' formerly representing a $>35-100 \%$ incidence was adjusted to $>50-100 \%$. On CBSD severity scale, the score 4 formerly representing a $>12-25 \%$ severity was adjusted to $>12-30 \%$; and the score 5 formerly representing an $>25 \%$ severity was adjusted to $>30-100 \%$ severity. Mean CBSD severity considered for 
computation was only for plants with scores of 2-5. In plants that became dually infected with CBSD and Cassava mosaic disease (CMD), the disease severity of CMD was also assessed as per Hillocks and Thresh (1998). Numbers of adult B. tabaci were also recorded monthly from five fully open top leaves on a shoot of each test plant. Experimental plants were allowed to grow for twelve months after which they were all uprooted and used to provide cuttings for a second season. CBSD incidences and severity with respect to individual cultivars and time (growth stage) were the basic parameters for the experiment.

The disease incidence and severity data were subjected to arc sine transformation and the whitefly count data subjected to $\log$ transformation as $\log (\mathrm{x}+1)$. These transformed data were statistically analysed using GenStat 4.24DE statistical package (VSN International Ltd). Analysis of variance (ANOVA) was performed to determine responses of test cultivars to CBSD based on foliar and stem incidences and severities of the disease. The mean values of observations were separated using Duncan's multiple range tests. Correlation test was done to determine the relationship among the measurable disease components.

Weather data were obtained from Tanzania Meteorological Agency (TMA) station based at Kibaha Research Station. Rainfall and temperature were considered to be the most important parameters for CBSD occurrence and therefore used to establish the relationship for the disease progress against weather variation. Microsoft excel software was used to develop the graphical presentation of the relationship between the selected weather data and CBSD severity based on foliar symptoms.

\section{Results}

\subsection{Response of the Test Varieties to CBSD and CMD and Whitefly}

Table 1. Description of visual diagnostic scale for CBSD used during the field survey

\begin{tabular}{|c|c|c|c|c|}
\hline $\begin{array}{l}\text { Disease } \\
\text { parameter }\end{array}$ & $\begin{array}{l}\text { Plant } \\
\text { part } \\
\text { assessed }\end{array}$ & $\begin{array}{c}\text { symptomatic } \\
\text { /damaged }\end{array}$ & $\begin{array}{l}\text { Score } \\
\text { scale }\end{array}$ & Description \\
\hline \multirow{17}{*}{$\begin{array}{l}\text { CBSD } \\
\text { incidence }\end{array}$} & \multirow{6}{*}{ Foliar } & & & \\
\hline & & $0 \%$ & 1 & None of the leaves has chlorosis characteristic for CBSD \\
\hline & & $1-5 \%$ & 2 & Very few leaves show faint chlorosis/blotches \\
\hline & & $5-30 \%$ & 3 & Appreciable number of leaves show chlorosis/blotches \\
\hline & & $30-50 \%$ & 4 & Half the leaves show chlorosis/blotches \\
\hline & & $50-100 \%$ & 5 & Almost all leaves show CBSD chlorosis \\
\hline & \multirow[t]{5}{*}{ Stem } & $0 \%$ & 1 & $\begin{array}{l}\text { No necrotic spot or lesion characteristic for CBSD seen on } \\
\text { stem }\end{array}$ \\
\hline & & $1-5 \%$ & 2 & A small part of the stem/one branch has necrotic spot \\
\hline & & $5-30 \%$ & 3 & Appreciable part of the stem has necrotic spot(s) \\
\hline & & $30-50 \%$ & 4 & Necrotic spot(s)/lesions apparent on stem(s) \\
\hline & & $50-100 \%$ & 5 & Necrotic spot(s)/lesions apparent of all branches/stems \\
\hline & \multirow[t]{6}{*}{ Root } & $0 \%$ & 1 & None of the roots has necrosis characteristic for CBSD \\
\hline & & & & Very small number of roots have necrosis characteristic for \\
\hline & & $0-5 \%$ & 2 & CBSD \\
\hline & & $5-30 \%$ & 3 & Appreciable roots have necrosis characteristic for CBSD \\
\hline & & $30-50 \%$ & 4 & Most roots have necrosis characteristic for CBSD \\
\hline & & $50-100 \%$ & 5 & Almost/all roots have necrosis characteristic for CBSD \\
\hline \multirow[t]{15}{*}{ CBSD severity } & \multirow[t]{5}{*}{ Foliar } & $0 \%$ & 1 & None of the leaves has chlorosis characteristic for CBSD \\
\hline & & $1-5 \%$ & 2 & Slight chlorotic spots characteristic of CBSD seen on leaves \\
\hline & & $5-12 \%$ & 3 & CBSD chlorotic spots/blotches easily observable on leaves \\
\hline & & $12-30 \%$ & 4 & Appreciable CBSD chlorotic spots/blotches seen on leaves \\
\hline & & $30-100 \%$ & 5 & Very severe chlorotic/necrotic blotches and leaf wilt \\
\hline & \multirow[t]{5}{*}{ Stem } & $0 \%$ & 1 & No necrotic spot or lesion is seen on stem \\
\hline & & $1-5 \%$ & 2 & Slight chlorotic spots on tender portion of the stem \\
\hline & & $5-12 \%$ & 3 & Necrotic spots are numerous, coalesced to small lesions \\
\hline & & $12-30 \%$ & 4 & Severe necrotic lesions enlarged into streaks \\
\hline & & $30-100 \%$ & 5 & Severe necrotic lesions, streaks, withering and die-back \\
\hline & \multirow[t]{5}{*}{ Root } & $0 \%$ & 1 & None of the roots has necrosis characteristic for CBSD \\
\hline & & $1-5 \%$ & 2 & Small portion of roots bears necrotic spots \\
\hline & & $5-12 \%$ & 3 & Appreciable proportion of the roots is obviously necrotic \\
\hline & & $12-30 \%$ & 4 & Roots mostly necrotic, not suitable for consumption \\
\hline & & $30-100 \%$ & 5 & Roots are almost/totally necrotic, started rotting \\
\hline
\end{tabular}


Table 2. Response of test cultivars to CBSD, CMD based on the leaf, stem and root incidence and severity of CBSD, CMD severity and mean B. tabaci count per plant in 2006/2007 and 2007/2008

\begin{tabular}{|c|c|c|c|c|c|c|c|c|c|}
\hline & *CBSD & & & & & & Roots & $* B$ & \\
\hline Tested varieties & F.inc. $(\%)$ & ${ }^{*}$ CBSD F.sev. & ${ }^{*}$ CBSD St.inc. $(\%)$ & *CBSD St.sev. & *CBSD R. inc(\%) & *CBSD R.Sev & no./plant & tabaci & ${ }^{*}$ CMD-sev. \\
\hline Albert & $43.64 \mathrm{~b}$ & $2.90 \mathrm{~b}$ & $19.25 \mathrm{c}$ & $1.52 \mathrm{c}$ & $18.51 \mathrm{a}$ & $1.83 \mathrm{a}$ & $0.29 b$ & $0.15 \mathrm{a}$ & $0.83 \mathrm{a}$ \\
\hline Namikonga & $7.46 \mathrm{a}$ & $1.06 \mathrm{a}$ & $5.55 \mathrm{a}$ & $0.96 \mathrm{a}$ & $20.62 \mathrm{a}$ & $1.78 \mathrm{a}$ & $0.31 \mathrm{~b}$ & $0.39 \mathrm{c}$ & $1.93 \mathrm{c}$ \\
\hline Kibaha & $45.10 \mathrm{~b}$ & $2.93 b$ & $18.61 \mathrm{c}$ & $1.50 \mathrm{c}$ & $21.75 \mathrm{a}$ & $1.85 \mathrm{a}$ & $0.26 \mathrm{ab}$ & $0.17 \mathrm{ab}$ & $1.47 \mathrm{~b}$ \\
\hline Nachinyaya & $42.80 \mathrm{~b}$ & $2.91 b$ & $5.53 \mathrm{a}$ & $0.95 \mathrm{a}$ & $36.90 \mathrm{~b}$ & $2.39 b$ & $0.32 b$ & $0.17 \mathrm{ab}$ & $1.62 b$ \\
\hline Cheupe & $49.10 \mathrm{c}$ & $3.20 \mathrm{c}$ & $9.28 \mathrm{~b}$ & $1.12 \mathrm{~b}$ & $37.83 b$ & $2.25 \mathrm{~b}$ & $0.17 \mathrm{a}$ & $0.20 \mathrm{~b}$ & $1.46 \mathrm{~b}$ \\
\hline
\end{tabular}

*Values followed by different letters in a column were significantly different as determined by Duncan's Multiple Range Test $(\mathrm{P} \leq 0.05)$. Abbreviations in a table: 'F.inc.' for foliar incidence, 'F.sev.' for foliar severity, 'St.inc.' for stem incidence and 'St.sev.' for stem severity score, 'R.inc.' for root incidence and 'R.sev.' for root severity scores of CBSD. 'CMD sev' for severity of cassava mosaic disease, 'B. tabaci' for mean number of adult whitefly count per shoot.

Duncan's mean separation tests indicated significant variation in response to CBSD and CMD by the tested cultivars (Table 2). The var. Namikonga was the least affected by CBSD while vars. Cheupe and Nachinyaya remained the highly affected in terms of leaf and root incidences and severities. Roots for the vars. Albert and Kibaha were lowly affected despite the severe symptoms in stems. Although var. Namikonga exhibited resistance to CBSD, it was the highest affected by CMD and was highly infested by the whitefly, B. tabaci. The vars. Cheupe, Kibaha and Nachinyaya were all moderately affected by CMD and had moderated number of whiteflies. Interestingly the var. Albert demonstrated resistance to CMD. Albert was also the least preferred by $B$. tabaci compared to other test cultivars. All the test cultivars had relatively low root weight and lowest root weights were recorded in var. Cheupe

\subsection{Combined Analysis for the Occurrence of CBSD, CMD and Whitefly}

The combined ANOVA for CBSD, CMD and whitefly occurrence during the 2006/2007 and 2007/2008 seasons was performed (Table 3). Results suggested that the leaf and stem incidences and severities of CBSD, the mean root weight and the number of adult $B$. tabaci were the most significant $(\mathrm{P}<0.001)$ disease indices among the parameters recorded. Stem symptoms were much less common than leaf symptoms. The Apart from CBSD, the test cultivars were also affected by CMD. The CMD severity was significant at $(\mathrm{P}<0.05)$.

Table 3. ANOVA for the combined incidences and severities of CBSD and CMD, and the mean number of $B$. tabaci on the five test cultivars during the 2006/2007 and 2007/2008 seasons

\begin{tabular}{llllllll}
\hline Source of variation & DF & MS & EMS & SED & LSD & P-value & CV (\%) \\
\hline CBSD leaf incidence (\%) & 4 & 3624.6 & 383.7 & 2.67 & 5.24 & $<0.001$ & 52.1 \\
CBSD leaf severity & 4 & 10.49 & 1.24 & 0.15 & 0.30 & $<0.001$ & 42.8 \\
CBSD stem incidence (\%) & 4 & 1927.39 & 86.94 & 1.27 & 2.50 & $<0.001$ & 80.1 \\
CBSD stem severity & 4 & 5.65 & 0.27 & 0.07 & 0.14 & $<0.001$ & 43.1 \\
CBSD root incidence (\%) & 4 & 2041 & 1266 & 4.84 & 9.51 & 0.170 & 131.2 \\
CBSD root severity & 4 & 5.12 & 3.10 & 0.24 & 0.47 & 0.159 & 87.0 \\
Mean weight/ root & 4 & 0.59 & 0.10 & 0.04 & 0.08 & $<0.001$ & 115.7 \\
B. tabaci per plant (mean) & 4 & 0.46 & 0.02 & 0.02 & 0.04 & $<0.001$ & 71.4 \\
CMD severity & 4 & 1.46 & 0.57 & 0.10 & 0.20 & 0.037 & 51.5 \\
\hline
\end{tabular}

Abbreviations in a table: 'DF', degrees of freedom, MS, mean square, 'EMS', error mean square, 'SED', standard error difference, 'LSD', Least significant difference, and 'CV', coefficient of variation,. 
Table 4. Partial correlation analyses among the disease parameters for CBSD and CMD, and the mean number of adult $B$. tabaci

\begin{tabular}{llllllllll}
\hline & F.inc. (\%) & F. sev. & St.inc. (\%) & St. sev. & R.inc. (\%) & R.sev. & Wt/root & B. tabaci & CMD sev. \\
\hline F. inc. (\%) & $\mathbf{1 . 0 0}$ & & & & & & & & \\
F. sev & $0.98^{* * *}$ & $\mathbf{1 . 0 0}$ & & & & & & & \\
St. inc. (\%) & $0.69^{* * *}$ & $0.69^{* * *}$ & $\mathbf{1 . 0 0}$ & & & & & & \\
St.sev & $0.72^{* * * *}$ & $0.76^{* * *}$ & $0.92^{* * *}$ & $\mathbf{1 . 0 0}$ & & & & & \\
R.inc. (\%) & $0.05^{\text {NS }}$ & $0.06^{\text {NS }}$ & $0.05^{\text {NS }}$ & $0.06^{\text {NS }}$ & $\mathbf{1 . 0 0}$ & & & & \\
St. sev & $0.08^{\text {NS }}$ & $0.08^{\text {NS }}$ & $0.07^{\text {NS }}$ & $0.08^{\text {NS }}$ & $0.85^{* * *}$ & $\mathbf{1 . 0 0}$ & & & \\
Root weight & $-0.02^{\text {NS }}$ & $-0.003^{\text {NS }}$ & $-0.013^{\text {NS }}$ & $-0.01^{\text {NS }}$ & $0.22^{* * *}$ & $0.21^{* * *}$ & $\mathbf{1 . 0 0}$ & & \\
B. tabaci & $-0.18^{* * *}$ & $-0.11^{* *}$ & $-0.15^{* * *}$ & $0.01^{\text {NS }}$ & $-0.05^{\text {NS }}$ & $-0.04^{\text {NS }}$ & $0.03^{\text {NS }}$ & $\mathbf{1 . 0 0}^{\text {No }}$ & \\
CMD sev. & $-0.09^{*}$ & $-0.002^{\text {NS }}$ & $-0.11^{* *}$ & $0.08^{\text {NS }}$ & $-0.003^{\text {NS }}$ & $0.011^{\text {NS }}$ & $0.02^{\text {NS }}$ & $0.58^{* * *}$ & $\mathbf{1 . 0 0}$ \\
\hline
\end{tabular}

*** Significant $(\mathrm{P}<0.01)$; ** significant $(\mathrm{P}>0.01)$; ${ }^{*}$ significant $(\mathrm{P}<0.05),{ }^{\mathrm{NS}}$ none significant.

Abbreviations in a table: 'F.inc.' for foliar incidence, 'F.sev.' for foliar severity, 'St.inc.' for stem incidence and 'St.sev.' for stem severity score, 'R.inc.' for root incidence and 'R.sev.' for root severity scores of CBSD. 'CMD sev' for severity of cassava mosaic disease, 'B. tabaci' for mean number of adult whitefly count per shoot.

\subsection{Relationships between CBSD Progress with Weather Parameters across Seasons}

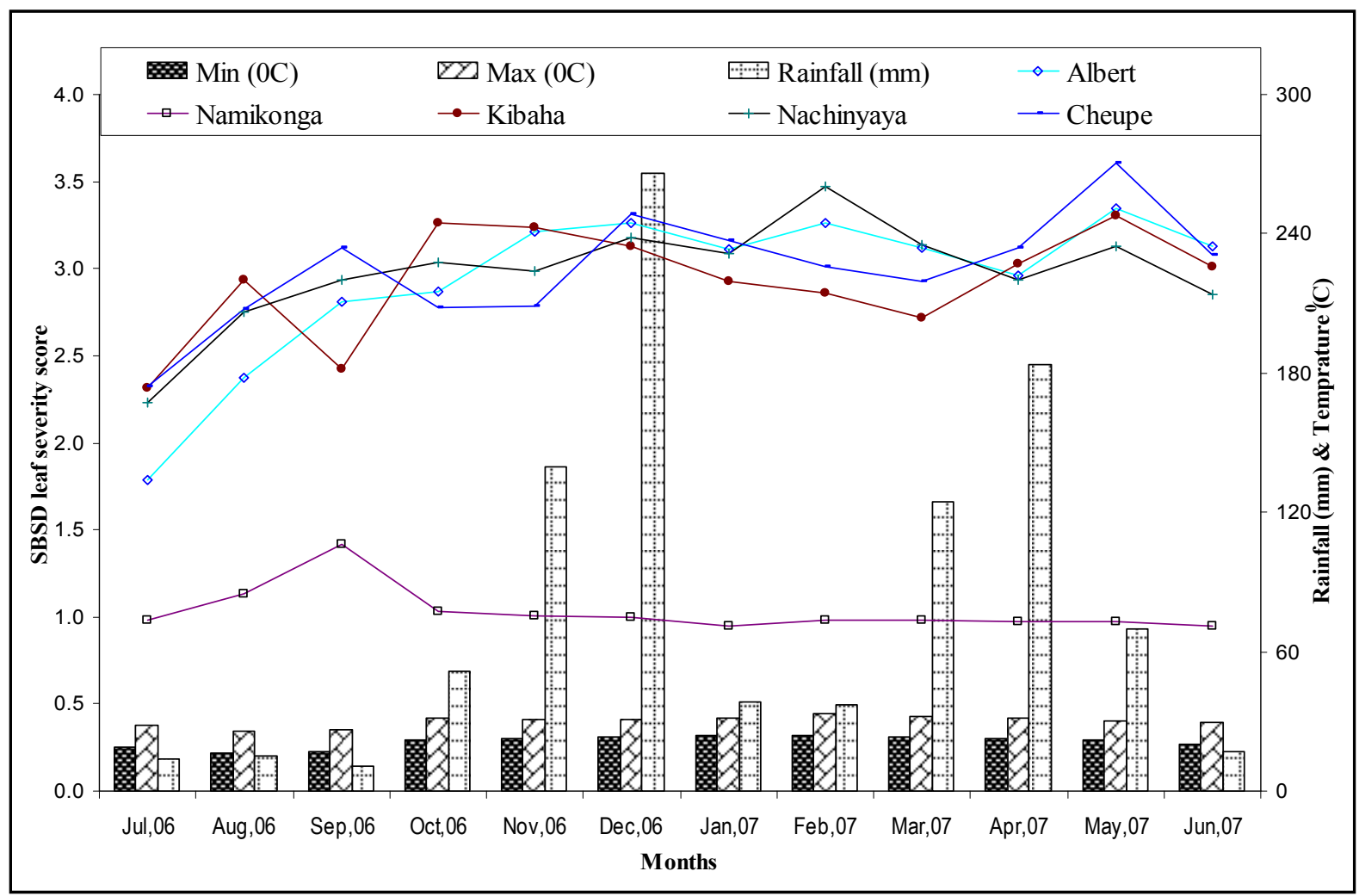

Figure 1. Relationship between the disease progresses based on CBSD leaf severity scores in the test varieties and rainfall and temperature during the 2006/2007 season

Results in Figure 1 shows the comparison between CBSD progresses in the season 2006/2007 based on disease severity in leaves and the major weather elements, the rainfall and temperature (minimum and maximum). Trends in disease severity indicates that var. Namikonga scarcely exhibited the disease symptoms due to the fact that the mean severity score rarely exceeded 1.0, except in September, 2006 when the highest CBSD severity score was 1.4 , recorded three months after planting. Clear differences were noted between the four susceptible test varieties (Albert, Cheupe, Kibaha \& Nachinyaya) and var. Namikonga. The CBSD severity scores for all the four varieties 
ranged from 1.8 in Albert to as high as 3.6 in Cheupe. The disease severity increased to the peak (score 3.5) at eight months after planting in var. Nachinyaya whereas in the other three varieties, the peak severity scores (Albert, 3.35; Cheupe, 3.6; \& Kibaha, 3.31) were recorded in May, eleven months after planting.

Despite the susceptibility of the four varieties (Albert, Cheupe, Kibaha \& Nachinyaya), and the increased disease severity as the plants grew, there was a slight decline in January and March to April, rising to the peak in May, 2007. The influence of rainfall and temperature was not so apparent, but the decline in disease severity peaks during the mentioned months would be associated with peaks in rainfall experienced in December 2006, and March and April, 2007. Lower temperatures in August and September, 2006 and from January to March, 2007 did not seem to relate to the disease severity trend.

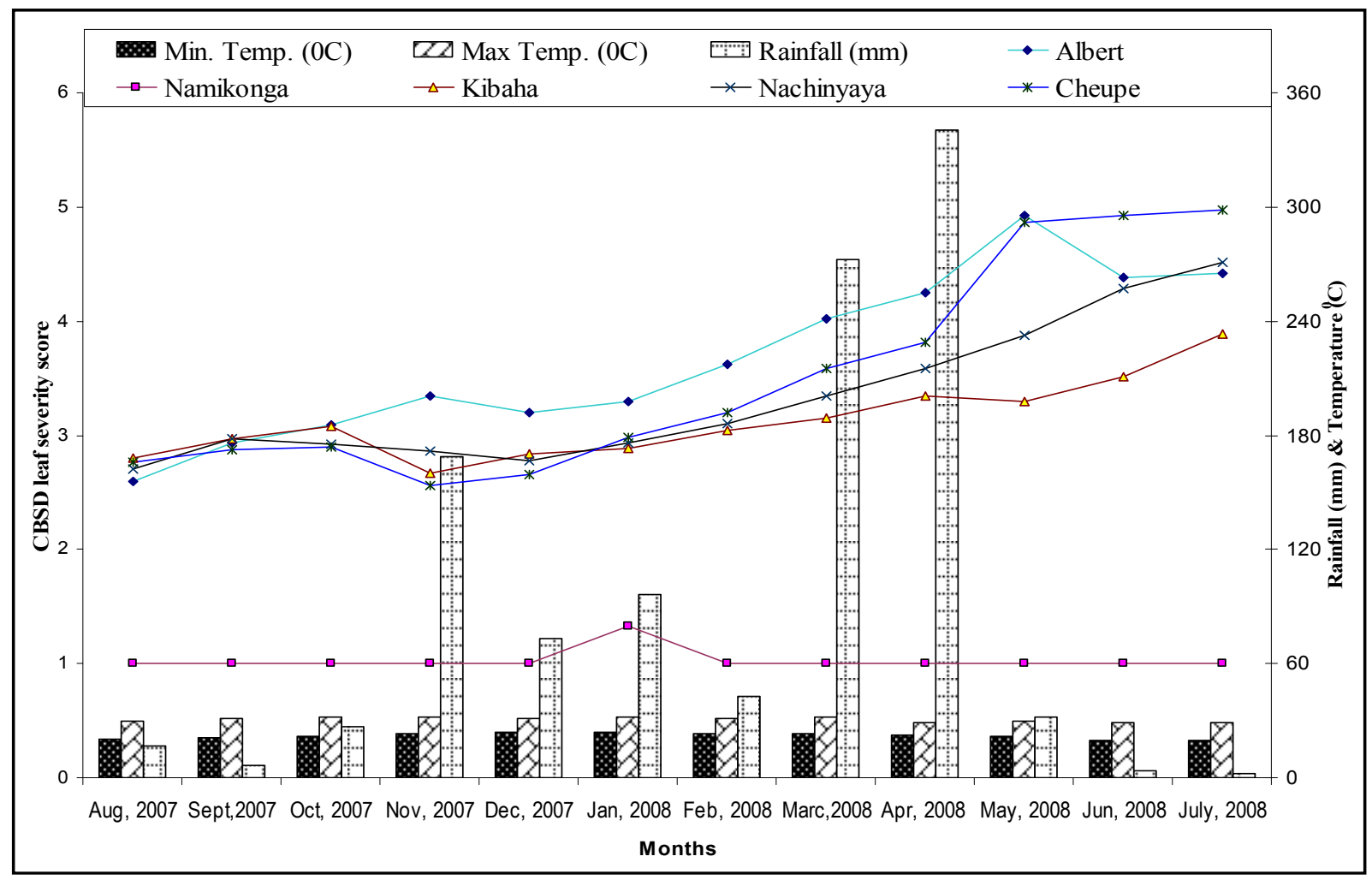

Figure 2. Relationship between the disease progress based on CBSD leaf severity scores in the test varieties and rainfall and temperature during the 2007/2008 season

During the 2007/08 season as data indicates in Figure 2, the var. Namikonga had the lowest disease severity scores compared to the other four test varieties. Similar trend was previously recorded during the 2006/2007 season. The CBSD severity increased with plant age. The highest disease severity score of 4.9 was recorded in May (ten months after planting) in the vars. Albert and Cheupe. Var. Cheupe almost maintained high severity level until at 12 months (the peak score 4.9) when harvesting was done, whereas, a notable decline of CBSD severity levels in the var. Albert was recorded from 4.9 to 4.4 at harvesting time. The disease severity in vars. Kibaha and Nachinyaya increased with plant age attaining the scores 3.9 and 4.5 respectively at the $12^{\text {th }}$ month when harvesting was done.

Unlike in 2006/07 season where rainfall seemed to have slight relationship with CBSD severity scores, none of the recorded disease indices (incidences and severities) during the 2007/08 season suggested any comparable trend with either rainfall or temperature parameters.

\subsection{Correlation among CBSD Indices, CMD, Harvested Root Weight and Whitefly Numbers}

Partial correlation was performed on CBSD indices, CMD severity and the recorded numbers of adult whitefly to test for their relationships and statistical significances (Table 4). Significant correlations were noted between CBSD leaf incidence and severities in leaves and stems as well as incidence in stems. The correlation between CBSD incidence and severity in stems was also significant. The CBSD incidence in roots had a significant relationship with the severity of the disease in roots and the mean root weight. The recorded number of adult 
whitefly significantly influenced CBSD incidence in leaves and stems as well as the disease severity in leaves. The severity of CMD was similarly influenced by the number of whitefly.

\section{Discussion}

Varied responses to CBSD were recorded among the tested cultivars in the field experiment. The incidence and severity of the disease was cultivar-specific. Throughout the experiments, var. Namikonga exhibited the lowest incidence and severity of disease while var. Cheupe was the most affected. Although all the experimental plants were obtained from CBSD-affected mother plants and grown in the same environment, severity data suggest that the disease was influenced by the inherent characteristics of individual cultivars. This observation is consistent with the Hillocks et al., (2001) and Jennings, (1960) reports that different cultivars respond differently to CBSD.

Symptoms for CBSD were clearly expressed on leaves compared to stems. Similar observations have been reported previously (Hillocks, 1997; Hillocks, 2003; Hillocks and Jennings, 2003; Nichols 1950). The observation confirmed that although CBSD was named after the stem symptoms, it is the foliar symptoms that are more likely to be seen and used for diagnosis (Nichols 1950).

The field occurrences of CBSD and CMD were independent of each other. Infection with either disease seemed not to affect the incidence and severity of the other. The CBSD resistant variety, Namikonga was seriously affected by CMD, whereas the CMD resistant var. Albert was badly affected by CBSD. The vars. Cheupe, Kibaha and Nachinyaya had susceptibility to both CBSD and CMD. Similar observations on varied responses of the different varieties to the two diseases were reported previously (Nichols, 1950a; Hillocks and Thresh, 1998; Hillocks and Jennings, 2003). The dual occurrences of the two diseases usually pose difficulties in their diagnosis through symptoms. This often demands for additional diagnostic step by molecular techniques which is expensive (Rwegasira, 2009). The nature of interaction between CBSD and CMD could be more apparent at molecular level than the observable incidences and severity of the diseases on the affected plants. A detailed study may be required in future to elucidate the nature of interaction between the two diseases.

Correlation analysis among the disease symptoms expression in leaves, stems and roots suggested that the occurrence of CBSD symptoms in any of the plant parts is interdependent and incidence of CBSD is often related to the severity in the respective plant part. Similar observations have been reported (Hillocks et al., 1996). The significant influence of whitefly on both CBSD and CMD disease indices concur with previous reports (Alicai et al., 2007; Maruthi et al., 2005; Ntawuruhunga and Legg, 2007) that the whitefly, B. tabaci is responsible for unlimited spread of the diseases throughout the Central, East and Southern parts of Africa.

Assessment of the disease progress in all the tested varieties (except var. Namikonga) indicated that CBSD severity increased with time. Thus, the intensity of foliar and stem symptoms (incidences and severity) increased as the plants grew. Despite some minor variations, the peak disease incidences and severities were attained at plant maturity, after 10 months or later in all susceptible cultivars. The observed trend was somewhat related to the Hillocks et al., (1999) report that the levels of disease damage depends on the time for which plants are infected. The longer the stay in the field the higher the damages expected from CBSD (Hillocks and Jennings, 2003). The amount of rainfall and temperature recorded had limited influence on the CBSD incidences and severities. Although other workers previously reported the influence of particularly temperature on CBSD severity levels (Nichols, 1950) and moisture stress (Rwegasira, 2009) the current lack of influence suggest that the recorded weather parameters were not too extreme to cause significant impact on the disease levels.

\section{Conclusion}

The findings from these studies have shown that foliar CBSD symptoms are more apparent compared to stem symptoms. The var. Namikonga proved to be resistant to CBSD although very susceptible to CMD. Other test cultivars, namely Albert, Cheupe, Kibaha and Nachinyaya were susceptible to CBSD but resistant to CMD. This observation suggests that the mechanisms and pathways for resistance to CBSD and CMD could be totally different. Despite the fact that some of the test cultivars like Cheupe, Kibaha and Nachinyaya were dually affected by CBSD and CMD, the former was more damaging compared to the later. Rainfall and temperature did not seem to influence the levels of CBSD but the disease incidences and severities increased with plants age. The numbers of B. tabaci significantly influence the occurrence of both CBSD and CMD. Therefore, the inherent genetically controlled response of different varieties to CBSD, the time for which the plant stays infected and the number of whiteflies, $B$. tabaci are among the important factors that determine the disease manifestation in CBSD-affected plants. 


\section{Acknowledgement}

We are grateful to the International Institute of Tropical Agriculture (IITA) for funding this study. Our gratitude is also due to the authorities at the Sugarcane Research Institute, Kibaha for allowing us to use their facilities. We are also indebted to scientists in the Root and Tubers Program at SRI-Kibaha, Ms. Helen Kiozya and Mr. Eustace Tolano for their tireless support during the field experimentation.

\section{References}

Alicai, T., Omongo, C. A., Maruthi, M. N., Hillocks, R. J., Baguma, Y., Kawuki, R., ... Colvin, J. (2007). Re-emergence of Cassava Brown Streak Disease in Uganda. Plant Disease, 91, 24-29. http://dx.doi.org/10.1094/PD-91-0024

EARRNET. (2005). Statement on the Consequences of New Spread of Cassava Brown Streak Virus Disease for Movement of Cassava Germplasm in the East and Central African Region. International Institute of Tropical Agriculture. 2pp. www.iita.org. Retrieved, $27^{\text {th }}$ May, 2010.

FAOSTAT. (2008). http://faostat.fao.org/faostat/servlet/xteservlet3. Retrieved $13^{\text {th }}$ May, 2010.

GenStat 4.24DE. (2005). The GenStat Discovery, 2nd Edition. VSN International Ltd. http://discovery.genstat.co.uk

Hillocks, R. J. (1997). Cassava virus disease and their control with special reference to southern Tanzania. Integrated Pest Management Reviews, 2, 125-138. http://dx.doi.org/10.1023/A:1018449017411

Hillocks, R. J. (2003). Cassava Brown Streak Virus Disease: Summary of Present Knowledge on Distribution, Spread, Effect on Yield and Methods of Control. Pp 23-27. In Legg J. P. and Hillocks R. J. (Eds), 2003. Cassava brown streak virus disease: Past, Present and Future. Proceedings of an International Workshop, Mombasa, Kenya, 27-30 October, 2002. Natural Resources International Limited, Aylesford, UK. pp. 100.

Hillocks, R. J., \& Thresh, J. M. (1998). Cassava mosaic and cassava brown streak virus diseases in Africa: a comparative guide to symptoms and aetiologies. Natural Resources Institute, UK. pp. 10.

Hillocks, R. J., \& Jennings, D. L. (2003). Cassava Brown Streak Disease: a review of present knowledge and research needs. International Journal of Pest Management, 49, 225-234. http://dx.doi.org/10.1080/0967087031000101061

Hillocks, R. J., Raya, M. D., \& Thresh, J. M. (1996). The association between root necrosis and above-ground symptoms of brown streak virus infection of cassava in southern Tanzania. International Journal of Pest Management, 42, 285-289. http://dx.doi.org/10.1080/09670879609372008

Hillocks, R. J., Raya, M. D., \& Thresh, J. M. (1999). Distribution and symptoms expression of cassava brown streak disease in southern Tanzania. African Journal of Root and Tuber Crops, 3, 57-61.

Hillocks, R. J., Raya, M. D., Mtunda, K., \& Kiozia, H. (2001). Effects of cassava brown streak virus disease on yield and quality of cassava in Tanzania. Journal of Phytopathology, 149, 389-394. $\mathrm{http}: / / \mathrm{dx}$. doi.org/10.1046/j.1439-0434.2001.00641.x

ICTV. (2005). Virus Taxonomy; Classification and Nomenclature of Viruses, $8^{\text {th }}$ Report of the ICTV. CM Fauquet, MA Mayo, J Maniloff, U Desselberger and L. A. Balls (Eds). Elsevier Academic Press, San Diego. pp. 841.

Jennings, D. L. (1957). Further studies in breeding cassava for virus resistance. East African Agricultural Journal, 22, 213-219.

Jennings, D. L. (1960). Observations on virus diseases of cassava in resistant and susceptible varieties to brown streak disease. Empire Journal of Experimental Agriculture, 28, 261-269.

Legg, J. P., \& Hillocks, R. J. (Eds). (2003). Cassava Brown Streak Virus Disease: Past, Present and Future. Proceedings of an International Workshop, Mombasa, Kenya, 27-30 October, 2002. Natural Resources International Limited, Aylesford, UK. pp. 100.

Maruthi, M. N., Hillocks, R. J., Mtunda, K., Raya, M. D., Muhanna, M., Kiozia, H., ... Thresh, J. M. (2005). Transmission of Cassava brown streak virus by Bemisia tabaci (Gennadius). Journal of Phytopathology, 153, 307-312. http://dx.doi.org/10.1111/j.1439-0434.2005.00974.x

Mkamilo, G. (2009). A review of cassava farming in Tanzania. Final Report. The National Roots and Tuber Crops Research programme. Aghricultural Researchi Institute, Naliendele, Mtwara, Tanzania. pp. 52. 
Monger, W. A., Seal, S., Cotton, S., \& Foster, G. D. (2001). Identification of different isolates of cassava brown streak virus and development of diagnostic test. Plant Pathology, 50, 768-775. http://dx.doi.org/10.1046/j.1365-3059.2001.00647.x

Munthali, D. C. (1992). Effect of cassava varieties on the biology of Bemisia afer. Insect Science and its Application, 13, 459-465.

Nichols, R. F. W. (1950). The brown streak disease of cassava: distribution, climatic effect and diagnostic symptoms. East African Agricultural Journal, 15, 154-160.

Ntawuruhunga, P., \& Legg, J. (2007). New Spread of Cassava Brown Streak Virus Disease and Its Implication for Movement of Cassava Germplasm in the East and Central African Region. p. 6. http://c3project.iita.org/Doc/A25-CBSDbriefMay6.pdf

Rwegasira, G. M. (2009). Aspects of epidemiology of cassava brown streak virus disease in Tanzania. PhD Thesis, University of the Witwatersrand, South Africa. p. 222.

Storey, H. H. (1936). Virus Diseases of East African Plants VI. A progress report on studies of the disease of cassava. East African Agricultural Journal, 12, 34-39.

Storey, H. H. (1939). Report of the plant pathologist. Annual Report from East African Agricultural Research Station for 1939.

Storey, H. H., \& Doughty, L. R., (1951). Virus disease of cassava. In East African Agriculture and Forestry Research Organisation(pp. 26-27). Annual Report for 1951. Zenith Printing Works Ltd, Nairobi. p. 88. 